\title{
CSF SHUNT INFECTION; PEADRIATIC CEREBROSPINAL FLUID SHUNT INFECTION. ANALYSIS OF RISK FACTORS INSTIGATING
}

\section{Dr. Muhammad Sohaib Anwer ${ }^{1}$, Dr. Muhammad Ali Waqas², Dr. Atta-ur-Rehman Khan ${ }^{3}$}

1. Assistant Professor Neurosurgery Sh. Zayed Hospital Rahimyar Khan. 2. Assistant Professor Neurosurgery Sh. Zayed Hospital Rahimyar Khan 3. Assistant Professor Neurosurgery Sh. Zayed Hospital Rahimyar Khan

Correspondence Address: Dr. Muhammad Sohaib Anwer Assistant Professor Neurosurgery Sh. Zayed Hospital Rahimyar Khan.

Article received on: 22/08/2016

Accepted for publication: 25/10//2016

Received after proof reading: $18 / 01 / 2017$
ABSTRACT... Hydrocephalus is the abnormal accumulation of CSF with in the ventricles and subarachnoid spaces. It is often associated with dilatation of ventricular system and increased ICP. Hydrocephalus is almost always a result of an interruption of CSF flow and rarely because of increased CSF production. The definitive treatment of hydrocephalus is surgical treatment which includes shunting and non-shunting procedures. The most common and overwhelming complications that can occur due to the CSF shunts is infection. The risk factors associated with pediatric CSF shunt infection has been analyzed in this study. Study Design: Descriptive study. Setting: Department of Neurosurgery, Nishtar Hospital Multan \& Sheikh Zayed Hospital Rahim Yar Khan. Period: Three years 01-07-2013 to 01-07-2016. Method: Total 209 eligible patients who were operated for CSF shunt were keenly monitored. Several variables were observed and the responses against these variables were noted down. Post operative follow up of all these cases done for 6 months in order to notice any development of infection (clinical signs of infection \& CSF examination) in CSF shunt system. Chi-square method was used applied in order to analyze the association among the variables and shunt infection development.In our population of 209 patients only twenty six patients (12.44\%) suffered from shunt infection. In this study four variables were qualified as having significant association with greater risk of shunt infection. 1) Patient age. 2) Inadvertently exposure of surgical instruments to the shunt system. 3) the existence of large number of previous shunt systems. 4) manual handling of shunt system Conclusions: Four variables have been reported by this study which can be a great source of shunt infection.it is recommended that changes in clinical practice should be considered in order to avoid these. Few recommendations are as follows. 1) While handling the shunt system great care should be taken. 2) It should be taken care that the manual contact of the Surgeons with the shunt system should be minimum. 3) it is recommended that the alternatives other then the shunt insertion should be considered especially for the children. 4) Great number of previous shunt system is also a great risk factor and these patients must be handled as individuals at high risk.

Key words: $\quad$ Cerebrospinal fluid shunt; Infection; Hydrocephalus; Neurosurgery; Children

Article Citation: Anwer MS, Waqas MA, Khan A. CSF Shunt Infection; Peadriatic cerebrospinal fluid shunt infection. Analysis of risk factors instigating. Professional Med J 2017;24(1):110-115. DOI: 10.17957/TPMJ/17.3593

\section{INTRODUCTION}

Like other numerous diseases of childhood such as spina bifida, brain tumors, brain hemorrhage, head injury and meningitis Hydrocephalus is also one of the childhood conditions which require insertion of cerebrospinal fluid shunt. But these CSF shunt often associated with different complications. The common complication in these CSF shunts are 3 to $15 \%$ infection rate andmore than $40 \%$ of two year failure rate. ${ }^{15,17,19,31,35,39,43}$ These shunt infections mostly occurs after few months of this shunt surgery and is linked up with several risks which include seizure disorder and decreased drainage.

These shunt infections can be cured by removing the inserted shunt system,time being insertion of an external CSF drain, a proper antibiotic course and finally re-insertion of new shunt system. This whole procedure involves a minimum of two separate surgery operations and two to three weeks hospital stay. Also there is equal chance of long term risk of mortality greater than $30 \%$ which is double in \% age as compared to the children without infection. 
Several researches and studies have been conducted for the identification of these factors and it has been revealed that no clear identification of these factors has been notified. All the data in previous literature came from retrospective series which does not show any clear agreement for identification of these CSF risk factors. So the need of this study was to identify those risk factors which should be consider for the CSF shunt infectionin children and identification of potentially modifiable perioperative practices.

\section{OBJECTIVES}

Objective of this study was to analyze prospectively the perioperative risk factors for CSF shunt infections in children.

\section{MATERIAL AND METHODS}

The descriptive case study was performed at Nishtar Hospital Multan \& SH. Zayed hospital Rahim yar khan in the neurosurgery departments. The total population of this study was comprised of 209 patients. The duration of this study was three years i.e. 01-07-2013 to 01-07-2016.

\section{Inclusion Criteria}

The eligible patients for this study were those whose age was between 1 year to below 16 years and if they are going for insertion of shunt or CSF shunt revision.

\section{Exclusion Criteria}

Those cases were not considered for the study, in which a history for shunt infection or any other infection in the body system was observed.

Two hundred and nine patients admitted in the departments of neurosurgery indoor and fulfilling the criteria were selected. Prior this study a verbal consent was taken from all those patients after clarifying them the nature and cause of the study. Moreover the procedure of the study was also explained to them. The study was conducted after obtaining the permission from the ethical committees of the hospitals.

A dedicated full time staff nurse was deputed to assist in the study whose duty was to identifythe pending shunt operations for the study from daily operation list. Staff nurse observed the whole procedure of surgery from the time the child entered in the theater till the time wound was closed and record the observations for the study. All the operation was performed by the same neurosurgeon.Patients were observed for CSF shunt infection up to 6 months postoperatively.

\section{Data Analysis}

Data was entered in the pre defined Performa. All the data was key punched and analyzed by using software SPSS 20.0. Frequencies were calculated for gender age and mean operation time.The variables to be studied were as follows gender, age, previous shunt system, priority level of operation i.e. ranging from 4 i.e. higher priority emergency cases to 1 i.e. lowest priority, elective cases, operation mean time, manual handling of VP shunt, no. of times shunt system was manipulated by a surgical instrument, nature of surgery either first time or revision surgery andnumber of person present in the theater. Chi square test was applied and asymptotic significance level as $p<0.05$ was selected for this study. Mean and standard deviation was also calculated for age and mean operation time.

\section{RESULTS}

The total population of this study was 209 patients including both male and female. Among these total count of male patients was 131 and for female patients it was 78 . The average patients age at the time of operation was $12.5 \pm 4$ years (range 02-17). Distribution of gender with respect to age is represented in the below mentioned Table-l.

The mean surgery time was $47.9 \pm 22.3 \mathrm{~min}$. Also the mean postoperative follow-up period was 6 months. The mean time to re-operate the patient with infection was 36 days (4-177 days). Out of 209 patients 183 patients were remain infection free after the completion of 6 months follow up period. While infection was observed in rest of 26 patients which are described as follows.

Our analysis revealed that four variables i.e. 
manual handling of VP shunt system $(p=0.002)$, manipulation of shunt system due to surgical instrument $(p=0.003)$ the patient age $(p=0.002)$ and greater number of Previous shunt (0.001) were proved as significant risk factor for these types of surgical operations. These are described as follows.

\begin{tabular}{|c|c|c|c|}
\hline \multirow{2}{*}{ Age Groups (In Years) } & \multicolumn{2}{|c|}{ Gender } & \multirow{2}{*}{ P-Value } \\
\hline & Male $(n=131)$ & Female $(n=78)$ & \\
\hline 01-05 & 14 & 05 & \multirow{4}{*}{0.002} \\
\hline 06-10 & 39 & 19 & \\
\hline $06-15$ & 36 & 28 & \\
\hline $16-20$ & 42 & 26 & \\
\hline Total & \multicolumn{2}{|c|}{209} & \\
\hline
\end{tabular}

\begin{tabular}{|c|l|c|c|c|}
\hline Sr. No & Reason & Total cases & Male & Female \\
\hline 1 & shunt system was manipulated by surgical instrument & 04 & 3 & 1 \\
\hline 2 & Manual handling of VP shuntsystem & 04 & 2 & 2 \\
\hline 3 & Greater number of Previous shunt & 18 & 15 & 3 \\
\hline
\end{tabular}

Manual handling of VP shuntsystem Infected

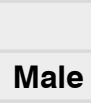

02

\section{Gender}

Female

02
P-value

0.002

Table-III. Cross-tabulation of manual handling of VP shunt system with respect to Gender

Shunt system was manipulated by surgical instrument Infected

\begin{tabular}{c|c|r}
\multicolumn{2}{|c|}{ Gender } & \multicolumn{1}{l}{ P-value } \\
\hline Male & Female & 0.003 \\
\hline 03 & 01 &
\end{tabular}

01

Table-IV. Cross-tabulation of infection with respect to Gender

\section{DISCUSSION}

It has been tried to identify those risk factors which cause CSF shunt infection. These have been identified by closely observing the shunt surgeries in children. Our study indicates that four variables which have significant relationship with a great risk of infection are as follows. 1) Patient age 2) inadvertently exposure ofsurgical instruments to the shunt system 3) the existence of large number of previous shunt systems 4) manual handling of shunt system.

\section{RISK FACTORS}

\section{Greater Number of Previous shunt system}

There are many reasons which can cause Hydrocephalus and hence ultimately requires the placement of a VP shunt. But apparently the root cause of hydrocephalus does not have any relationship with the infection risk for shunt. The occurrence of shunt infection lies between $1.6 \%$ and $16.7 \% .{ }^{44,45}$ It is pertinent to mention that the reason behind such a great percentage of infection incidence is mainly due to are due to patient demographics and varying definitions of infections in VP shunt system. These are also evident through the literature review.

Till date no clear guideline or proper recommendationsfor the early identification/ detection of CSF shunt infection is available. Nevertheless, it is evident from past literature that few authors have proposed recently few standardized approaches in order to handle these infections ${ }^{46}$ Mostly the shunt infection starts after the placement of shunt or revision (e.g. within 1 month); and subsequently is the occurrence of contamination due to microorganisms. ${ }^{44,4}$ Also it 
is pertinent to that the chances of increase rate of infection rate are high due to the advance number of shunt revision..$^{48}$ In fact, it is more appropriate to say that rate of occurrence of infection in those patients which have revision of shunt system are more riskyas compare to those patients who do not have any shunt revision.

The above mentioned statistics are very important tobe noted due to the reason that by a rough estimate more then $50 \%$ cases CSF shunt require at least one surgery for revision in later stages. ${ }^{45,46}$

Bayston and Lari $^{3}$ observed and declared in a study of sample size of 100 CSF shunt operations, that $58 \%$ of patients of hydrocephalus, have the existence of previous shunt system. ${ }^{1,36}$ In our study the presence of previous shunt system can a risk factor is proved. In our study 18 patients has previous shunt system thus causing the infection making the percentage as $8.61 \%$.

\section{Age of the Patient}

In previous study few authors reported that the younger patients are more prone to the risk of infection while others reported in negative. ${ }^{10,21,29,31-33,37}$

But in our study evidences has been found that the patients of younger than 4 yearsthere is a are more prone to risk at the time of shunt surgery as compare to the children older than this. The attributable factors which are the main cause of increase rate of infection are poor skin condition, poor immune system, generally, and high density of skin bacteria. ${ }^{7,12}$ So it is recommended that the alternatives other then the shunt insertion should be considered especially for the children. ${ }^{2,20}$

\section{Manual handling of Shunt System}

In this study the overallfrequencyof infection due to manual handling the shunt system was $15.38 \%$. These results are quite similar to the other studies in which chances of infection due to manual handling of shunt system have been observed up to 12 to $20 \%$. $^{9,13,14,27,30}$

\section{Exposure of Shunt System to the surgical}

\section{Instruments}

It is also evident from our results thatdue to increase touching of the shunt system can be a source of higher risk of infection. Moreover exposure of shunt system to surgical instrument can also cause infection in children.

All these findings indicate that the role of surgical personnel can be a great source of contamination which in turn causes infection in CSF shunt systems.

In our study, any other variable did not reveal significant results. It is quite a possibility, that this study do not have adequate powers to identify all significant variables. ${ }^{24,25,33}$

\section{CONCLUSIONS}

In this study four factors have acknowledged for the cause of shunt infection, and it is recommended that changes in clinical practice should be considered in order to avoid these. Few recommendations are as follows. 1) While handling the shunt system great care should be taken. 2) It should be takencare that the manual contact of the Surgeons with the shunt system should be minimum. 3) it is recommended that the alternatives other then the shunt insertion should be considered especially for the children. 4) Great number of previous shunt system is also a great risk factor and these patients must be handled as individuals at high risk.

These findings can also be used as particle implications for other surgeries.

Copyright (C) 25 Oct, 2016.

\section{REFERENCES}

1. Ammirati $M$, Raimondi AJ: Cerebrospinal fluid shunt infections in children. A study on the relationship between the etiology of the hydrocephalus, age at the time of shunt placement, and infection rate. Childs NervSyst 3:106-109, 1987.

2. Anonymous: Randomised trial of early tapping in neonatal posthaemorrhagic dilatation: results at $\mathbf{3 0}$ months. Ventriculomegaly Trial Group. Arch Dis Child Fetal Neonatal Ed 70:F129-F136, 1994.

3. Bayston R, Lari J: A study of the sources of infection in colonized shunts. Dev Med Child Neurol 32 (Suppl 6):16-22, 1974. 
4. Bennett $B$, Duff $P$ : The effect of double gloving on frequency of glove perforations. ObstetGynecol 78:1019-1022, 1991.

5. Berg GA, Kirk AJB, Bain WH: Punctured surgical gloves and bacterial re-colonisation of hands during open heart surgery: implications for prosthetic valve replacement. Br J ClinPract 41:903-906, 1987.

6. Bondurant $\mathrm{CP}$, Jimenez DF: Epidemiology of cerebrospinal fluid shunting. Pediatric Neurosurg 23:254-259, 1995.

7. Borgbjerg BM, Gjerris F, Albeck MJ, et al: Risk of infection after cerebrospinal fluid shunt: an analysis of 884 first-time shunts. ActaNeurochir 136:1-7, 1995.

8. Chadduck W, Adametz $\mathrm{J}$ : Incidence of seizures in patients with myelomeningocele: a multifactorial analysis. SurgNeurol 30: 281-285, 1988.

9. Chapman S, Duff P: Frequency of glove perforations and subsequent blood contact in association with selected obstetric surgical procedures. AmJObstetGynecol 168:1354-1357, 1993.

10. Choux M, Genitori L, Lang D, et al: Shunt implantation: reducing the incidence of shunt infection. JNeurosurg 77:875-880, 1992.

11. Cohn GM, Seifer DB: Blood exposure in single versus double gloving during pelvic surgery. Am J ObstetGynecol 162:715-717, 1990.

12. Davis SE, Levy ML, McComb JG, et al: Does age or other factors influence the incidence of ventriculoperitoneal shunt infections? PediatrNeurosurg 30:253-257, 1999.

13. Dodds RDA, Barker SGE, Morgan NH, et al: Selfprotection in surgery: the use of double gloves. $\mathrm{Br} \mathrm{J}$ Surg 77:219-220, 1990.

14. Dodds RDA, Guy PJ, Peacock AM, et al: Surgical glove perforation. BrJSurg 75:966-968, 1988.

15. Drake JM, Kestle JRW, Milner R, et al: Randomized trial of cerebrospinal fluid shunt valve design in pediatric hydrocephalus. Neurosurgery43:294-305, 1998.

16. Drake JM, Kulkarni AV: Cerebrospinal fluid shunt infections. Neurosurg Q 3:283-294, 1993.

17. Faillace WJ: A no-touch technique protocol to diminish cerebrospinal fluid shunt infection. SurgNeurol 43:344-350, 1995.

18. Gani JS, Anseline PF, Bissett RL: Efficacy of double versus single gloving in protecting the operating team. AustN Z J Surg 60:171-175, 1990.
19. Horgan MA, Piatt JH Jr: Shaving of the scalp may increase the rate of infection in CSF shunt surgery. PediatrNeurosurg 26:180-184, 1997.

20. International PVHD Drug Trial Group: International randomized controlled trial of acetazolamide and furosemide in posthaemorrhagic ventricular dilatation in infancy. Lancet 352:433-440, 1998.

21. James HE, Bejar R, Gluck L, et al: Ventriculoperitoneal shunts in high risk newborns weighing under 2000 grams: a clinical report. Neurosurgery 15:198-202, 1984.

22. James HE, Walsh JW, Wilson HD, et al: Prospective randomized study of therapy in cerebrospinal fluid shunt infection. Neurosurgery 7:459-463, 1980.

23. Jensen SL, Kristensen B, Fabrin K: Double gloving as self-protection in abdominal surgery. EurJSurg 163:163-167, 1997.

24. Kestle JRW, Hoffman HJ, Soloniuk D, et al: A concerted effort to prevent shunt infection. Childs NervSyst 9:163-165, 1993.

25. Kontny U, Hofling B, Gutjahr P, et al: CSF shunt infections in children. Infection 21:89-92, 1993.

26. Mancao M, Miller C, Cochrane B, et al: Cerebrospinal fluid shunt infections in infants and children in Mobile, Alabama. ActaPaediatr 87:667-670, 1998.

27. McCue SF, Berg EW, Saunders EA: Efficacy of doublegloving as a barrier to microbial contamination during total joint arthroplasty. JBone Joint Surg (Am) 63:811-813, 1981.

28. McLone DG, Czyzewski D, Raimondi AJ, et al: Central nervous system infections as a limiting factor in the intelligence of children with myelomeningocele. Pediatrics 70:338-342, 1982.

29. Meirovitch J, Kitai-Cohen Y, Keren G, etal: Cerebrospinal fluid shunt infections in children. Pediatrlnfect Dis $\mathrm{J}$ 6:921-924, 1987.

30. Nicolai P, Aldam $\mathrm{CH}$, Allen PW: Increased awareness of glove perforation in major joint replacement. A prospective, randomized study of Regent Biogel Reveal gloves. J Bone Joint Surg (Br) 79:371-373, 1997.

31. Piatt JH Jr, Carlson CV: A search for determinants of cerebrospinal fluid shunt survival: retrospective analysis of a 14-year institutional experience. Pediatr Neurosurg 19:233-242, 1993.

32. Pople IR, Bayston R, Hayward RD: Infection of 
cerebrospinal fluid shunts in infants: a study of etiological factors. J Neurosurg77:29-36, 1992.

33. Renier D, Lacombe J, Pierre-Kahn A, et al: Factors causing acute shunt infection. Computer analysis of 1174 operations. JNeurosurg 61:1072-1078, 1984.

34. Ronan A, Hogg GG, Klug GL: Cerebrospinal fluid shunt infections in children. PediatrInfect Dis J 14:782-786, 1995.

35. Schiff SJ, Oakes WJ: Delayed cerebrospinal-fluid shunt infection in children. PediatrNeurosci 15:131$135,1989$.

36. Serlo W, Fernell E, Heikkinen E, et al: Functions and complications of shunts in different etiologies of childhood hydrocephalus. Childs NervSyst 6:92-94, 1990.

37. Shapiro S, Boaz J, Kleiman M, et al: Origin of organisms infecting ventricular shunts. Neurosurgery 22:868$872,1988$.

38. Van den Broek PJ, Lampe AS, Berbée GAM, et al: Epidemic of prosthetic valve endocarditis caused by Staphylococcus epidermidis. BrMed J 291:949-950, 1985.

39. Walters BC, Goumnerova L, Hoffman HJ, et al: A randomized controlled trial of perioperative rifampin/ trimethoprim in cerebrospinal fluid shunt surgery. ChildsNervSyst 8:253-257, 1992.

40. Walters BC, Hoffman HJ, Hendrick EB, et al: Cerebrospinal fluid shunt infection. Influences on initial management and subsequent outcome. JNeurosurg 60:1014-1021, 1984.
41. Wang EEL, Prober CG, Hendrick BE, et al: Prophylactic sulfamethoxazole and trimethoprim in ventriculoperitoneal shunt surgery. A double-blind, randomized, placebo-controlled trial. JAMA251:11741177, 1984.

42. Welch $\mathrm{K}$ : Residual shunt infection in a program aimed at its prevention. Z Kinderchir 28:374-377, 1979.

43. Younger JJ, Simmons JCH, Barrett FF: Operative related infection rates for ventriculoperitoneal shunt procedures in a children's hospital. Infect Control 8:67-70, 1987.

44. George RL, Leibrock L, Epstein M. Long-term analysisof cerebrospinal fluid shunt infections: a 25year experience. JNeurosurg. 1979; 51(6):804-811.

45. Korinek AM, Fulla-Oller L, Boch AL, Golmard JL, Hadiji $B$, Puybasset L. Morbidity of ventricular cerebrospinal fluidshunt surgery in adults: an 8-year study. Neurosurgery 2011; 68: 985 - 995.

46. Borgbjerg BM, Gjerris F, Albeck MJ, Borgesen SE. Risk of infection after cerebrospinal fluid shunt: an analysis of884 first-time shunts. ActaNeurochir (Wien). 1995; 136: 1-7.

47. Overturf GD. Defining bacterial meningitis and other infectionsof the central nervous system. PediatrCrit CareMed. 2005; 6(suppl):S14-S18.

48. Ragel BT, Browd SR, Schmidt RH. Surgical shunt infection: significant reduction when using intraventricular and systemic antibiotic agents. JNeurosurg. 2006; 105:242-24.

\section{AUTHORSHIP AND CONTRIBUTION DECLARATION}

\begin{tabular}{|c|c|c|}
\hline Sr. \# & Author-s Full Name & Contribution to the paper \\
\hline 1 & Dr. M. Sohaib Anwer & $\begin{array}{l}\text { Concept of study, Data } \\
\text { Collection, Data Analysis } \\
\text { and manuscript writing and } \\
\text { checking }\end{array}$ \\
\hline 2 & Dr. Muhammad Ali Waqas & $\begin{array}{l}\text { Concept of study, Data } \\
\text { Collection, Data Analysis } \\
\text { and manuscript writing and } \\
\text { checking }\end{array}$ \\
\hline 3 & Dr. Atta-ur-Rehman Khan & $\begin{array}{l}\text { Concept of study, Data } \\
\text { Collection, Data Analysis } \\
\text { and manuscript writing and } \\
\text { checking }\end{array}$ \\
\hline
\end{tabular}

Author $=\mathbf{s}$ Signature

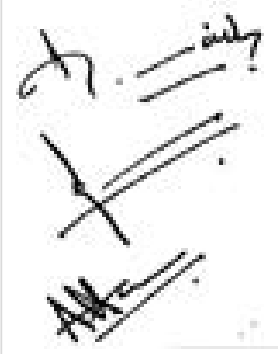

